\title{
Recent Advances in the Laser Forming Process: A Review
}

\author{
Mehdi Safari ${ }^{1, * \mathbb{D}}$, Ricardo Alves de Sousa ${ }^{2} \mathbb{D}$ and Jalal Joudaki ${ }^{1} \mathbb{D}$ \\ 1 Department of Mechanical Engineering, Arak University of Technology, Arak 38181-41167, Iran; \\ joudaki@arakut.ac.ir \\ 2 Department of Mechanical Engineering, Center for Mechanical Technology an Automation, \\ University of Aveiro, Campus de Santiago, 3810-183 Aveiro, Portugal; rsousa@ua.pt \\ * Correspondence: m.safari@arakut.ac.ir; Tel./Fax: +98-86-33400672
}

Received: 18 September 2020; Accepted: 2 November 2020; Published: 4 November 2020

check for updates

\begin{abstract}
Laser forming is an emerging manufacturing process capable of producing either uncomplicated and complicated shapes by employing a concentrated heating source. The heat source movement creates local softening, and a plastic strain will be induced during the rise of temperature and the subsequent cooling. This contactless forming process may be used for the simple bending of sheets and tubes or fabrication of doubly-curved parts. Different studies have been carried out over recent years to understand the mechanism of forming and predicting the bending angle. The analysis of process parameters and search for optimized manufacturing conditions are among the most discussed topics. This review describes the main recent findings in the laser forming of single and multilayer sheets, composite and fiber-metal laminate plates, force assisted laser bending, tube bending by laser beam, the optimization technique implemented for process parameters selection and control, doubly-curved parts, and the analytical solutions in laser bending. The main focus is set to the researches published since 2015 .
\end{abstract}

Keywords: laser forming process; laser bending; doubly-curved surfaces; optimization; tube bending

\section{Introduction}

Sixty years have passed since the day Theodore H. Maiman built the first laser in 1960 at Hughes Research Laboratories. Since then, different types of laser were invented and improved for use in industries and laboratories. Two recent review papers are currently published and address various aspects of using laser technology. Dixit et al. [1] and Das and Biswas [2] published review papers on laser forming in 2015 and 2018, respectively. However, laser technology, applied in manufacturing technology, can be viewed from a completely different prism. The "LASER" acronym stands for Light Amplification by Stimulated Emission of Radiation. A single phase-coherent beam can be focused on a tiny spot, and according to the power of the laser source, different processes are developed. The low magnitude power leads to surface treatment and annealing of the workpiece; increasing the laser power leads to the melting of the workpiece and welding. High power lasers melt and evaporate the workpiece, and metal cutting happens. The number of photons controls the power of the laser and the frequency emitted from the light source. The ability for industrial applications varies from $100 \mathrm{~W}$ to more than $5 \mathrm{~kW}$. Forming is another type of process, which can be implemented by laser technology. The workpiece can be a flat plate (sheet) or tube.

Laser beam irradiation induces thermal stresses into the worksheet. Temperature gradient mechanism (TGM), buckling mechanism (BM), and upsetting mechanism (UM) are three proposed mechanisms that happen during the laser beam irradiation [3,4]. The cooling of the sheet, at last, leads to bending the sheet due to residual stresses and corresponding strains. By increasing the temperature during laser beam 
irradiation, the physical properties of the sheet include yield strength, ultimate tensile strength, and the elastic (Young) modulus will also be decreased. The yield strength of the material decreases faster than the elastic modulus.

Consequently, the equivalent (von Mises, for instance) stress proportional to the elastic modulus overtakes the yield strength in some regions of the sheet. So, plastic deformation occurs over the irradiated zone. The amount of plastic deformation depends on both the pre-stress field and temperature distribution in the sheet. The more massive plastic strain will be obtained by higher peak temperatures and larger pre-stresses [5]. The laser beam specifications, the scan pattern, and the properties of the sheet determine the final shape of the workpiece. Reasonable attempts have been made by researchers in recent years to investigate the effect of laser irradiation path on the quality, productivity, and shape of the final workpiece. In the laser forming process, the heating of the workpiece is non-uniform and asymmetric. The beam irradiates from one point of the workpiece and scans along a defined path. The geometry condition is not constant along the heating line. So, an unwanted deformation will be created in the sheet called the "edge effect". This undesirable deformation reduces the forming accuracy. By introducing the laser forming technology, new applications responded in various industries. Bending of small parts with little bending angle (less than $1^{\circ}$ ), bending of complicated parts for aerospace industries such as tailor machined blanks (TMB), bending of low diameter tubes with minimum ovality and thickness variations, forming of composite parts with little delamination, and forming of doubly curved specimens to obtain the irradiating patterns which can be used in the flame forming of the dome and saddle-shaped parts in ship bodies are examples of the industrial applications of laser forming.

\section{Laser Bending of Monolithic Sheets}

Sheet bending is a vital manufacturing process which can be performed using laser technology. The sheet is scanned along a straight line, and local heating of one of the sheet's surfaces leads to the plastic deformation of the sheet due to the stress gradient over the thickness direction. The process parameters affecting the bend angle are laser characteristics (laser power, spot size, scan speed, pulsed or continuous irradiation), the number of irradiation passes, material type, and the geometrical dimension of the sheet (thickness, width, length). The literature survey shows that laser power is the most influential process parameters in the laser forming process. The coating of the sheet is also necessary. Graphite is a typical coating that absorbs the irradiated beam effectively. The retention of heat in the coating layer for a longer duration affects the out-of-plane bending and minimizes the residual stresses [6]. The rougher surface (such as sandblasted surfaces) and thicker coating layer increase the absorptivity of the laser beam and lead to higher bending angle [7]. Microstructural observation using electron backscatter diffraction (EBSD) technique shows that the grain size does not influence the final bending angle [8]. Cement and lime are two other coatings used in experiments, and the results show that the cement coating creates more deformation and bending than the lime coating $[9,10]$. Pulsed or continuous irradiation of the laser beam is also essential. Pulsed irradiation beam with overlapping the pulses increases the bending angle, and the existence of a gap between the pulses reduces the final bending angle [11].

In the laser forming process, the sheet bends only with the laser beam, and no die, punch, or external tools except the mounting fixture are needed for forming. The forming is contactless. Here resides of the most significant advantages of this process. The small and local deformations by the laser beam form the part. Without a smooth deformation field, it is difficult to form a non-smooth component. The effect of varying the scan distance, the number of passes per scan line, and the number of scan lines on the profile of the bend are essential. Overlapping of the laser beam paths is required to create a continuous smooth bend [12]. The bending angle enhanced about $20 \%$ in multi-pass laser forming, but the bending rate decreased at higher passes. The numerical and experimental studies show that the relative variation of the residual plastic strain decreases with the increase in laser irradiation pass [13]. 
The material of the bent sheet is also important. Thermal and mechanical properties have a significant effect on the forming outcome. Steel alloys are the most common materials in published research [13-16]. Aluminum alloys, titanium, and magnesium are other common materials [4,8,17-25]. The main differences of different materials types are the melting temperature, mechanical properties variation by temperature, the heat conductivity of the material, and laser beam absorption. The forming of magnesium alloys is vital due to brittle material behavior and low elongation at failure. Dixit et al. [17] studied the bending of friction stir welded AA5052-H32 aluminum alloy sheets experimentally and numerically. The irradiation of the laser beam changes the mechanical properties of the welded zone hardness distribution. The input heat in the irradiated zone refines the microstructure of the bent zone, and small refined grains at the top layer, followed by large elongated grains, will be produced in the heat-affected zone. The grain refinement leads to an increase in micro-hardness. The slip and twinning mechanisms also can be activated in the heat-affected zone according to the processing condition. The input heat in laser forming improves the micro-hardness of the heat-affected zone in the sheet $[8,15]$. By increasing the thermal gradient and heat flux from a specified limit, the grains can grow, and the hardness will decrease with an increase in the grain size [19]. In the laser forming of steel sheets, ferrite and pearlite will form due to heating and cooling. The average grain size varies from 6 to $10 \mu \mathrm{m}$ [20]. The residual stress distribution is also affected by the input heat flux [21,23]. Fetene et al. [18] studied the effect of width and thickness on the multi-pass laser bending of AH36 steel strips experimentally and numerically. The absorption coefficient of the irradiated beam affects the bending angle. It can be obtained with experimental tests and inverse problem solution by finite element software such as ABAQUS, COMSOL MULTIPHYSICS, or ANSYS software $[17,18,24]$. The finite element analysis is usually carried out with a 3D nonlinear transient thermo-mechanical solver. The temperature and strain-rate dependent material properties of the sheet are required. The coupled thermal-structural analysis allows us to predict the bending angle with reasonable accuracy [24-26]. Safari and Ebrahimi studied the laser bending of perforated sheets [27] numerically. The results show that the bending angle decreases by increasing the diameters of the hole in the laser-formed perforated sheets. Figure 1 shows selected samples fabricated by laser forming.

The main challenge in the numerical modeling concerns the constitutive law to mimic the stress-strain behavior at elevated temperature, the heat transfer, and heat source models $[4,25]$. Higher material conductivity leads to higher heat transfer, and the heat-affected zone increasing. Consequently, the bending angle decreases. Air convection during beam irradiation is also essential [19]. Forced cooling by air and natural convection of air are compared [25], and results show that significant improvement had been obtained by forced cooling of air in the multi-scan laser bending process. The possibility of Martensite phase formation should be considered in the bending of steel alloys. Paramasivan et al. [24] investigated the simultaneous use of laser beam irradiation (at the top of the sheet) and a coaxial external cooling source (at the bottom of the sheet). The results showed that the bending angle increased by about $20 \%$ due to the increase in heat transfer and the temperature gradient between the top and the bottom of the sheet. The magnitude of induced residual stresses increased with an increase in cooling source diameters while the heat-affected zone decreased. The heat transfer in multi-pass laser forming is essential. Cooling time should be considered between repetitive passes to avoid surface oxidation and material melting. The conductivity of material and cooling conditions (forced or natural convection) can affect the production time and the productivity of the process in mass production [28]. Table 1 shows some of the main researches about the laser bending of single sheets.

Different aspects of laser bending have been investigated numerically and experimentally. The material of most of the researches is ductile. It seems that new methods of bending brittle materials are needed. Further aspects exist in the development of the laser forming process. The bending of pre-formed samples can be an advancement in this field. For example, the bending of a sheet with an elongated hole in the bending area (which was created by a cutting die) and bending the lateral edge of a stretch formed sheet such as a car body are two examples of pre-formed cases. The minimum radius of bending is essential. The problem is, "Can laser bending technology fabricate a sheet with zero 
bending radius?". The possibility of using laser bending technology for assembling sheets is another interesting topic in this field. The behavior of laser-formed sheets in fatigue loading, creep condition, working at corrosive circumstance (high humidity, contact with the seawater, higher temperature), and comparison to conventional bending processes can help us judge the operational condition of laser-formed samples. Combining the laser bending with other laser-based processes such as laser beam machining (LBM) or laser beam welding (LBM), or even additive manufacturing and performing both processes simultaneously can produce more complicated and cheaper parts.

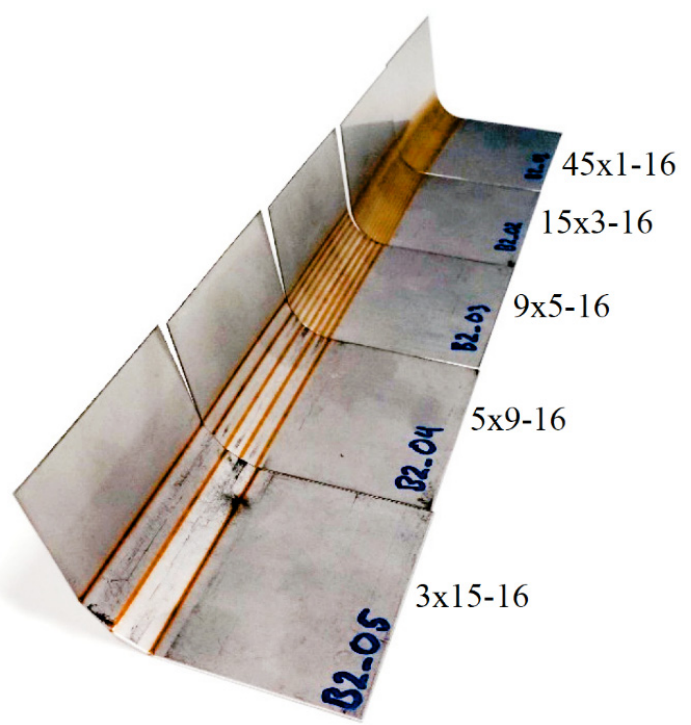

(a)

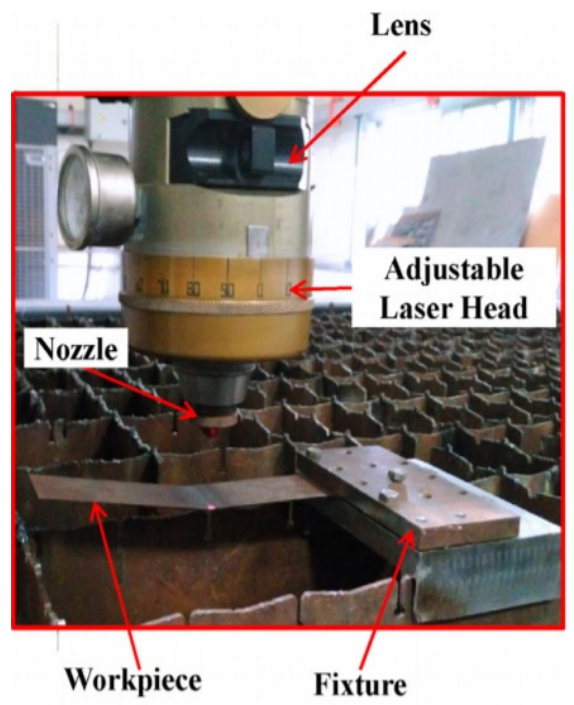

(c)

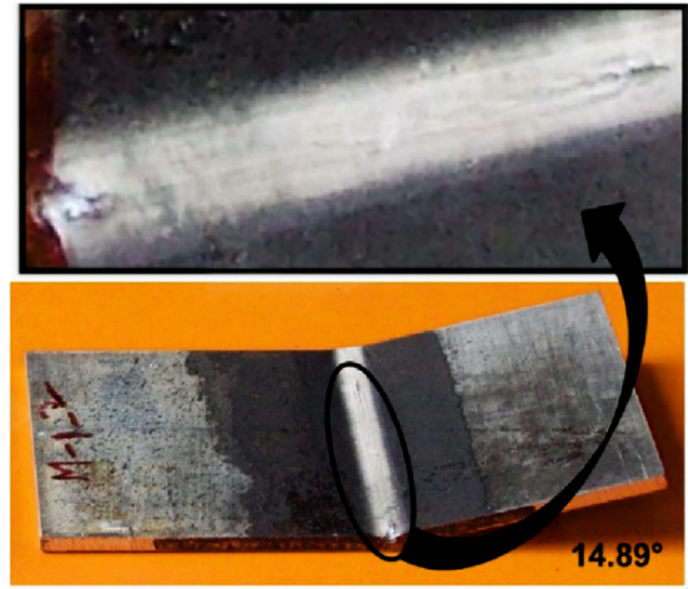

$P=300 \mathrm{~W}, \mathrm{~V}=1000 \mathrm{~mm} / \mathrm{min}, D=3.87 \mathrm{~mm}$

(b)

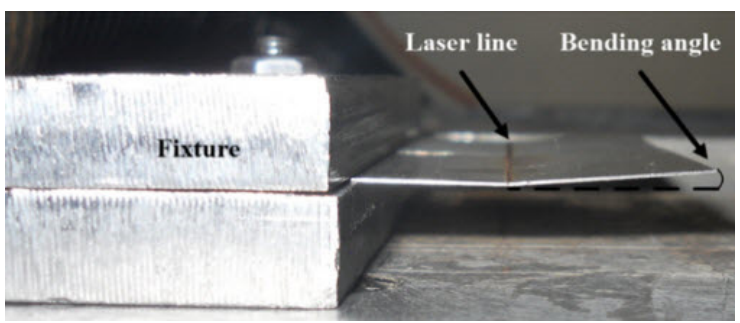

(d)

Figure 1. (a) Bending of the sheet by multi-pass irradiation [12], (Adapted from [12], with permission from Elsevier, 2020). (b) Laser bending by multi-scan laser bending [22], (Adapted from [22], with permission from Elsevier, 2020). (c) Laser bending of AH36 steel [18], (Adapted from [18], with permission from Elsevier, 2020). (d) Laser forming of AISI 304-stainless steel sheet with surface roughness and $\mathrm{Cr}_{2} \mathrm{O}_{3}$ oxide layer created [7], (Adapted from [7], with permission from Elsevier, 2020). 
Table 1. Comparison of the leading researches in the laser bending of monolithic sheets.

\begin{tabular}{|c|c|c|c|}
\hline Reference & Material & Laser Specification & Blank Dimensions \\
\hline Zhang et al. [13] & DP980 steel & $\begin{array}{l}220 \mathrm{~W} \text { laser; } 2.5 \mathrm{~mm} \text { spot diameter; } 20 \\
\mathrm{~mm} / \mathrm{min} \text { scan speed }\end{array}$ & $\begin{array}{c}80 \mathrm{~mm} \times 80 \mathrm{~mm}, 1.8 \mathrm{~mm} \\
\text { thickness }\end{array}$ \\
\hline Zhang et al. [14] & DP980 steel & $\begin{array}{l}750-1250 \mathrm{~W} \text { laser; } 5.2 \mathrm{~mm} \text { spot diameter; } \\
2-5 \mathrm{~m} / \mathrm{min} \text { scan speed }\end{array}$ & $\begin{array}{c}100 \mathrm{~mm} \times 50 \mathrm{~mm}, 1.4 \mathrm{~mm} \\
\text { thickness }\end{array}$ \\
\hline Maji et al. [15] & AISI 304 stainless steel & $\begin{array}{l}225-275 \mathrm{~W} \text { laser; } 0.5-0.75 \mathrm{~mm} \text { spot } \\
\text { diameter; } 250-283 \mathrm{~mm} / \mathrm{s} \text { scan speed }\end{array}$ & $\begin{array}{c}120 \mathrm{~mm} \times 40 \mathrm{~mm}, 0.5 \mathrm{~mm} \\
\text { thickness }\end{array}$ \\
\hline Song et al. [16] & $\begin{array}{l}\text { Ultra-high strength steel } \\
\text { sheet SPFC1180Y }\end{array}$ & $\begin{array}{l}\text { 500-1000 W laser; } 5 \mathrm{~mm} \text { spot diameter; } \\
2-10 \mathrm{~m} / \mathrm{min} \text { scan speed }\end{array}$ & $\begin{array}{c}100 \mathrm{~mm} \times 50 \mathrm{~mm}, 1.2 \mathrm{~mm} \\
\text { thickness }\end{array}$ \\
\hline Fetene et al. [18] & AH36 (mild) steel & $\begin{array}{c}500-700 \mathrm{~W} \text { laser; } 7.6-11.4 \mathrm{~mm} \text { spot } \\
\text { diameter; } 800-1000 \mathrm{~mm} / \mathrm{min} \text { scan speed }\end{array}$ & $\begin{array}{l}120 \mathrm{~mm} \text { length, } 20-40 \mathrm{~mm} \\
\text { width, } 1-2 \mathrm{~mm} \text { thickness }\end{array}$ \\
\hline Mjali et al. $[19,21]$ & $\begin{array}{l}\text { Commercially pure } \\
\text { grade } 2 \text { titanium alloy }\end{array}$ & $\begin{array}{c}\text { 1500-3500 W laser; } 12 \mathrm{~mm} \text { spot } \\
\text { diameter; } 1.6-2.6 \mathrm{~m} / \mathrm{min} \text { scan speed }\end{array}$ & $\begin{array}{c}200 \mathrm{~mm} \times 50 \mathrm{~mm}, 3 \mathrm{~mm} \\
\text { thickness }\end{array}$ \\
\hline Kant and Joshi [22] & Magnesium M1A alloy & $\begin{array}{l}\text { 300-500 W laser; } 3.87-7.74 \mathrm{~mm} \text { spot } \\
\text { diameter; } 1-3 \mathrm{~m} / \mathrm{min} \text { scan speed }\end{array}$ & $\begin{array}{c}70 \mathrm{~mm} \times 40 \mathrm{~mm}, 1.9 \mathrm{~mm} \\
\text { thickness }\end{array}$ \\
\hline Kotobi and Honarpisheh [23] & $\begin{array}{l}\text { Commercially pure } \\
\text { grade } 2 \text { titanium alloy }\end{array}$ & $\begin{array}{l}1600 \mathrm{~W} \text { laser; } 3 \mathrm{~mm} \text { spot diameter; } 6 \\
\mathrm{~m} / \mathrm{min} \text { scan speed }\end{array}$ & $\begin{array}{c}70 \mathrm{~mm} \times 40 \mathrm{~mm}, 0.6 \mathrm{~mm} \\
\text { thickness }\end{array}$ \\
\hline
\end{tabular}

\section{Laser Bending of Bi-Layer and Tailored Blanks}

The previous section discussed the forming of single, monolayer, homogenous sheets. The properties and thickness of the sheet were assumed as constant. However, different properties of the sheet can be obtained by increasing the number of layers (bi-layer sheets or multilayer sheets), manufacturing a composite sheet, or different thickness or material (tailor welded blanks (TWB), tailor machined blanks (TMB)). Doing so, the laser-induced bending mechanism and magnitude of bending will be different. Safari et al. [29] investigated the laser bending of tailor machined blanks (TMB) experimentally. Tailor-made blanks are sheet metal assemblies with different thicknesses and/or materials and/or surface coatings. The laser melts the sheet, and bending happens due to plastic deformation during solidification. The thickness affects the bending angle. Different thicknesses, start point of scan and absorbed power by the sheet (laser power and scanning speed) influence the bending magnitude of the TMB sheet. The thick-to-thin irradiation path creates a higher bending angle in comparison to the thin-to-thick irradiation path. Increasing the laser power, reducing the laser scan speed and irradiation of the laser beam from the back of the sheet (the side of the sheet that the step does not rely on) enhances the bending angle of tailor machined blanks. The bending angle of laser-formed tailor-machined blanks can be predicted by the artificial neural network (ANN) [30].

Seyedkashi et al. [31] investigated the laser forming of stainless steel $304 \mathrm{~L}$ and Copper $11000 \mathrm{clad}$ sheets using $200 \mathrm{~W}$ laser power. Clad sheets are types of tailored properties sheets. The laser beam creates a high-temperature gradient along the thickness direction. The portion of heat received by the sheets is different, and due to non-uniform plastic deformation, the bending angle, residual stress distribution, and microstructure are different in clad sheets.

Kotobi and Honarpisheh [32] studied the laser forming of St-Ti bilayer sheets. The induced residual stress distribution along the thickness is measured experimentally by the slitting method. The bending angle increases by increasing the laser power and number of scanning passes and reducing the scanning velocity. The higher residual stress will be induced in the workpiece, and a higher bending angle will be obtained. A relation between the bending angle and maximum residual stress has been derived [33]. Research has shown that the thermal properties of layers affect the thermally affected depth and lead to the smaller plastic zone. Consequently, a smaller bending angle will be obtained [34-36].

The thickness is another critical process parameter. Higher laser power is needed for bending thicker sheets. The sheet bending creates due to the temperature gradient induced in the sheet. So, for the bending of thick sheets, a steeper temperature gradient across the sheet thickness should be produced. Higher laser power ( 2 to $3 \mathrm{~kW}$ ) and lower scan speed create such temperature gradient and deform the sheet [37]. The springback decreases by increasing the thickness. Thinner sheets may be 
bent with significantly lower laser power (about $400 \mathrm{~W}$ ) and higher scan speed, but the springback will be increased. The authors propose that a comprehensive study performs the residual stress distribution along with the thickness for bi-layer and TMB bent samples. This residual stress distribution can be measured with experimental methods and used for assessing the performance of the fabricated parts. Moreover, by developing a new type of materials and parts like functionally graded materials (FGM), shaped memory alloys (SMA) parts, and powder metallurgy parts, more investigation is needed to understand the mechanism of bending by the laser beam.

\section{Laser Forming of Composite Sheets}

The effect of material type and layers configuration on the laser-formed sheets were discussed in previous sections. In this section, the laser forming of composite sheets will be discussed. The type of composite is essential. Fiber and matrix have different mechanical properties (yield strength, stress-strain behavior) and physical properties (melting point, density, conductivity). Seyedkashi et al. [38] investigated the laser forming of three-layered SUS430/C11000/SUS430 laminated composite sheets. The copper mid-layer has higher thermal conductivity than the stainless steel 430 sheets. The plastic strain, along with the thickness and the shear stress between the layers, is more complicated than a single monolithic layer. Warping is another problem in the laser bending of composite samples. During the laser forming of stainless steel-carbon steel composite plate in ANSYS software, the non-uniform heat distribution and different heat conductivity and heat loss produce a warping force which causes undesirable deformation of composite in addition to the edge effect [39]. The sequence of layers is also important and affects the bending angle of the multilayer composite samples [40].

Fiber-Metal Laminates (FML) are made of different layers of metal and composite material. The difference between the properties of fiber, matrix, and metal leads to complicated plastic deformation, bending, and unpredictable. The complicated deformation mechanisms, interfacial delamination, and thermal alteration of the layers are three main challenges in the laser forming of FMLs. However, using the experimental test and using an artificial neural network tool made it possible to predict the behavior of FMLs during the laser bending process [41,42]. Moreover, the deformation of FMLs can be predicted using Eigen-strain field prediction $[43,44]$. The composites are divided into three categories, polymer matrix composite (PMC), ceramic matrix composite (CMC), and metal matrix composite (MMC). By increasing the use of MMC parts and the easy fabrication of PMC parts, more study is needed to fabricate the MMC and PMC made parts by laser beam technology. The use of MMC materials is increasing rapidly in the aerospace industry.

\section{Force Assisted Laser Bending}

To increase the bending angle of laser-formed sheets, applying an external force is a helpful solution. The applied force causes more bending, and sharp bending angles can be obtained [45]. The springback phenomenon is crucial, and the accuracy of forming is affected by the change in the angle of the bent sample after unloading. The springback has a close relation to the distribution of induced residual stresses during forming. The external force (bending moment) is created by a hydraulically driven tool, preload weight, or a screw-driven rod [46-48]. Fuzzy logic models and trained artificial neural network (ANN) with verified FEM models can predict the bending angle [49,50]. Figure 2 shows the mechanism of applying an external force for laser-assisted bending of titanium samples.

The proper combination of laser heating and external force increases the bending angle up to $140^{\circ}$, considerably decreases springback (10 times on titanium and 30 times on aluminum alloy), and reduces the risk of rupture during bending at high angles in comparison with conventional bending processes. Moreover, using an assistant force can decrease the edge effect in the laser bending process. Shi et al. [51] proposed a method consisting of applying two unequal concentrated forces, which reduce the edge effect up to $80 \%$ in comparison to the pure laser bending process. In a recent trial, the electromagnetic force is used for force assisted laser bending [52,53]. The electromagnetic 
force is a non-contact tool that can bend the sheet more precisely by controlling the electric current and air gap between the electromagnet and sheet. Moreover, the straightening (unbending) of bent samples was carried out by the electromagnetic force. The distributed load instead of point load is the main advantage of electromagnetic force, despite the more challenging control of electromagnetic force.
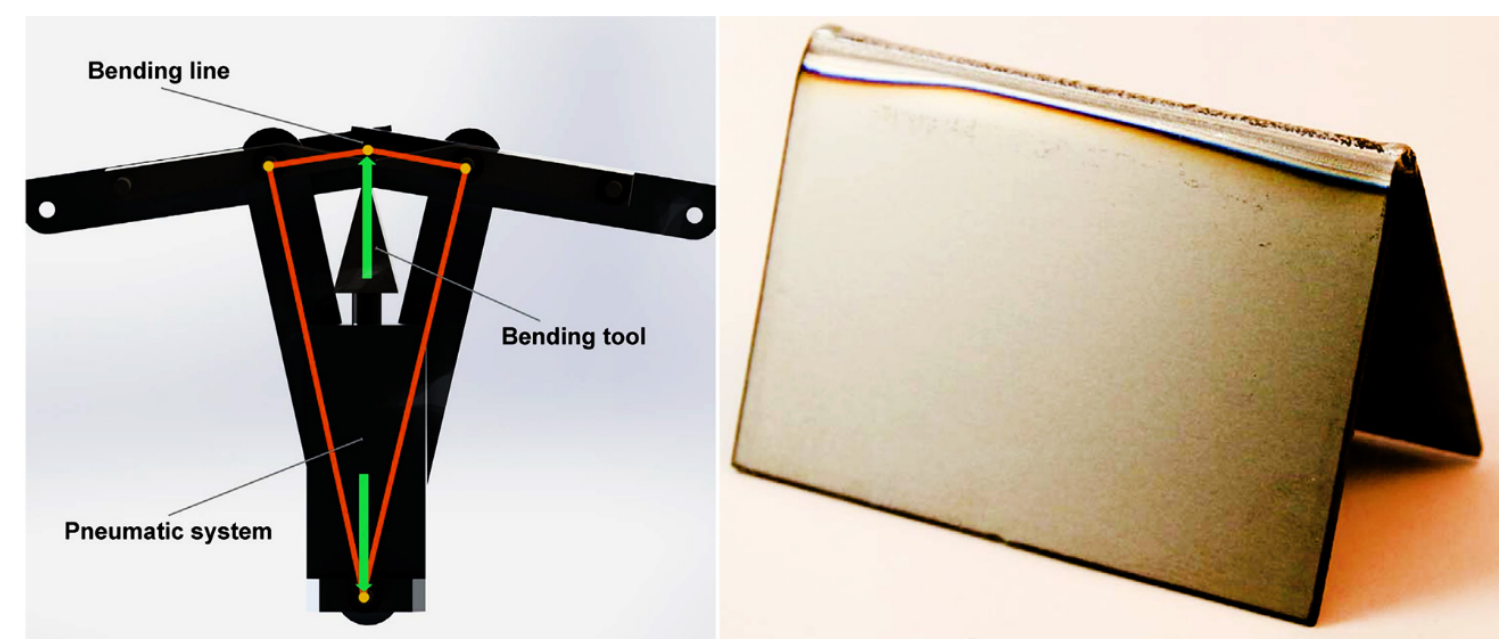

Figure 2. Bending mechanism of titanium sheet by applying an external force and the final fabricated sample [46]. (Adapted from [46], with permission from Elsevier, 2020).

\section{Laser Tube Bending}

Tube bending was always a challenge in conventional bending. Usually, an internal plug is inserted inside the tube, and bending happens. However, a laser beam can also be used for tube bending. The laser beam is irradiated on the tube surfaces and may result in 2D or 3D tube bending. The amount of research about tube bending is low in comparison to the laser sheet metal forming. The effects of the irradiating length and the number of irradiating passes on tube bending have been studied. Three primary defects of the laser tube bending are lateral bending angle (especially when the scanning path is complicated like spirals), ovality, and thickness variation. The tube bending angle increased by increasing the irradiation length and number of passes. Moreover, the ovality percentage and the thickness variation will be increased by increasing the irradiation length [54]. The circular scanning method can be used for 2D and 3D tube bending. A scanning strategy has been developed to determine the scanning path using direct and reverse solution [55]. The effect of process parameters is like sheet metal forming, and the bending angle of the tube increases by increasing the laser power and beam diameter and with a decrease in the travel speed [56]. Figure 3 shows two samples of laser tube forming. Laser beam absorption can also be performed to improve the obtainable bending angle [57]. Different materials, such as carbon steel, stainless steel, and nickel tubes, can be formed and used in various industries such as aerospace industries, engines, heat exchangers, and air conditioners [54-60]. Statistical tools, such as Particle Swarm Optimization (PSO), can predict the bending angle and compensation of springback [58]. The Taguchi design of experiment, Artificial Neural Networks (ANN), and genetic algorithm (GA) are standard statistical tools which can find the optimized condition to obtain maximum bending angle, minimum ovality, minimum thickening, and minimum forming energy consumption [60].

The size of the tube is another essential process parameter. Normal sizes, such as $1 / 2$ and $3 / 4$ inch tubes, can be formed using a laser beam without difficulties. However, the laser forming of micro-tubes (for example, a tube with $635 \mu \mathrm{m}$ outer diameter) needs more precise tools and controlled conditions [59,61]. The micro-tubes are thin-walled structures, due to high thermal conductivity and quick heat dissipation from the irradiated zone, short pulse, and high power laser beams utilized for inducing plastic strain and tube bending. It seems that researchers only focus on the bending of 
round tubes. Rectangular tubes, especially the 3D bending of them, is an attractive subject of study. The ovality of 2D and 3D laser-formed tubes and thinning of the tube is also important and needs more investigation.
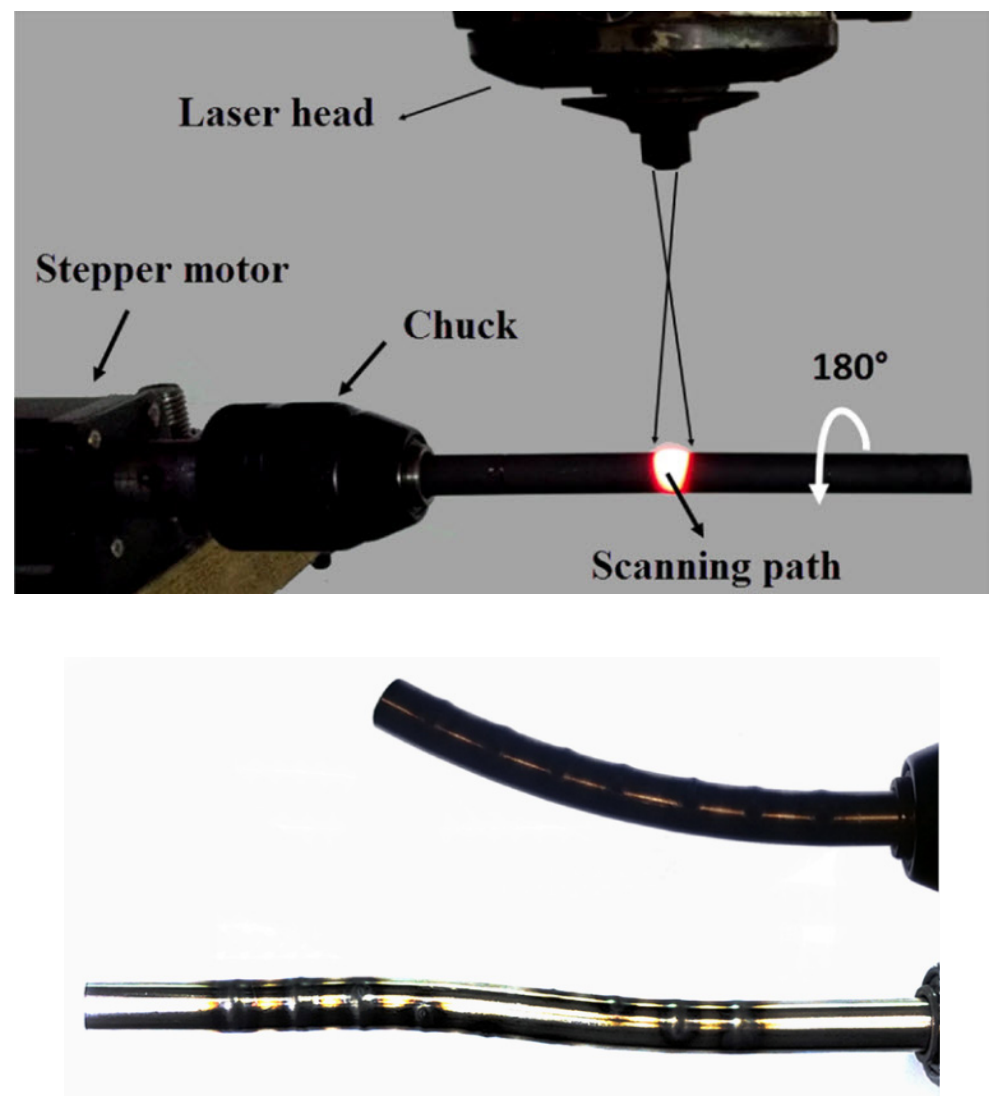

Figure 3. 2D and 3D tube bending [55]. (Adapted from [55], with permission from Elsevier, 2020).

\section{Optimization}

The selection of process parameters is crucial in laser forming. A comprehensive analytical model which determines the bending angle of the sheet during laser forming has not been derived until now. This is mostly due to the complicated nature of laser forming. Interaction between structural and thermal loadings and coupled thermo-elastic-plastic loading prevents a specified and comprehensive analytical model. In this way, statistical tools are powerful tools for finding the effect of process parameters and determining the behavior of the sheet during laser forming. Full factorial design of experiments, response surface methodology, fuzzy logic strategy, Particle Swarm Optimization (PSO), Artificial Neural Network (ANN), Taguchi approach, Genetic Algorithm (GA), and other statistical tools are implemented to derive an equation for prediction of bending angle $[4,15,28,41,49,60,62-71]$. The number of experiments is vital in the accuracy of the derived equation. The number of process parameters for laser forming (including laser power, pulse or continuous irradiation, beam diameter, scan speed, irradiation scheme, number of passes, material type, thickness, etc.) is high, and studying the effect of process parameters is not possible experimentally. So, in most studies, a finite element analysis using commercial FEM codes (ABAQUS, ANSYS, COMSOL MULTIPHYSICS, ... ) is verified by experimental tests and the other set of experiments simulated by FEM. If two levels are selected for investigation for eight listed laser forming parameters, $2^{8}$ experiments (256 experiments) should be carried out by full-factorial design, which is almost impossible to be carried out experimentally. Reducing the number of experiments leads to neglecting the interaction of some process parameters. 
For example, Omidvar et al. [64] used the Taguchi orthogonal design of experiments (four factors-five levels) to find a maximum bending angle for a $1 \mathrm{~mm}$ thick AA6061-T6 sheet. Twenty-five experiments had been carried out to find the maximal bending angle of $28.7^{\circ}$. Similar research was conducted by Behera et al. [71]. The main difference between Taguchi and other designs of experiments is the aim of the Taguchi method, in which the robust control of parameters leads to less uncertainty in the fabricated workpiece. Kant et al. [65] developed an integrated FEM-ANN approach to calculate the bend angle with an artificial neural network (ANN) tool. Ponticelli et al. [49] used a fuzzy logic model to forecast the inherent uncertainties in the laser-assisted bending process and control of the springback. The optimal condition is determined according to the least-cost planning methodology (LCPM) to reduce the number of passes and use the highest laser power. Moreover, a combination of fuzzy logic controller and particle swarm optimization (PSO) methods is proposed by the researchers to find the proper set of input parameters to catch a predefined bending angle [67]. In laser forming, the bending angle and thickening of the sheet due to shrinkage are essential. Combining the genetic algorithm (GA) and neural network (genetic algorithm-based neural network (GANN)) helps for the proper determination of the effect of the input parameters on bending angle and thickening [68].

In most of the statistical models, the effectiveness of process parameters on output can be determined. The portion of each process parameters differ. Usually, laser-induced heat characteristics (laser power, pulse duration, and scan speed) are the most significant process parameters. However, the laser power cannot be increased above the melting point of the material, which will lead to the burning of material or formation of spongy debris on the surface of the sheet [69]. ANalysis Of VAriance (ANOVA) is a powerful tool for determining the effectiveness of each input parameter. Typically, a regression equation is derived which relates the output parameter to any arbitrary input parameters. The fitting quality and the range of process parameters affect the precision of estimation. Multi-objective optimization can be used to find the maximum temperature, maximum bending angle, and/or maximum residual stress. The optimization technique used in the above references focuses on the classical and standard optimization technique used frequently in manufacturing processes. By developing new optimization techniques such as grey wolf optimization (GWO), ant colony optimization (ACO), scatter search (SS), self-organizing migrating algorithm (SOMA), and combined metaheuristic optimization techniques such as simulated annealing-artificial neural networks (SA-ANN) and Powell simulated annealing with combinatorial optimization (PSACO) algorithm, it is possible to find the optimized condition for the fabrication of complicated shapes by the laser forming process.

\section{Doubly Curved Parts}

The laser beam irradiation path is an important parameter that can be used for shaping complicated parts including bowl-shaped surfaces, cylindrical surfaces, saddle-shaped surfaces, and intricate 3D shapes. In the laser-bending of sheets, the beam is irradiated along a straight line and bend the sample. However, using different scanning paths like spiral movement, concentric circles, crossed lines, spider pattern movement, and other developed scanning strategies make a complicated plastic strain field in the sheets and form the sheet to the desired shape. The tolerance of forming is a challenge that affects the effectiveness of the laser forming process. The curved parts can be used in shipbuilding, a cranial prosthesis (from Ti-6Al-4V titanium alloy for use in the skull) [72], Origami Spoon [73,74], and cylindrical shells. Gisario et al. [75] used radial paths to fabricate a dome from flat stainless steel blank. Maji et al. [68] used response surface methodology (RSM) to find the optimum process parameters to fabricate dome-shaped surfaces. The thickness of the sheet is crucial in doubly curved parts. Kant et al. [3] used a curvilinear path for forming of thick and thin sheets. The results show that the bend angle increases with a decrease in scanning path curvature in thick sheets. Different scanning paths can be utilized for the fabrication of curved parts. Table 2 shows some of the leading research in this field [76]. Several pieces of research have been published by the authors, which focus on the forming of saddle shapes by the spiral movement of the laser beam source [76-85]. 
The experience of the authors shows that concurrent consideration of the process parameters leads to better prediction of curvature. The proposed method for the design of experiments is response surface methodology (RSM). A comparison of spiral path movement with a circular irradiation path shows that a smoother curvature will be obtained while using a spiral path strategy. Moreover, the radial circular path forms the workpiece according to the buckling mechanism (BM), whereas the spiral irradiation pattern will result in a gradient mechanism (GM) [85,86]. Different materials, including mild steel, AISI 316 stainless-steel sheet [87], Galvanized iron [88], and AISI 304 stainless steel [89], were successfully formed by the researchers. Some researchers developed general scanning paths according to the circular irradiation path and showed that a precise workpiece could be fabricated using finite element modeling [90,91]. Figure 4 shows examples of doubly curved parts manufactured by laser forming. Most of the researchers focus on finding a proper irradiation scheme for forming of doubly curved shapes from a straight blank. However, forming doubly-curved specimens in multi-steps-for example, forming one curve and then re-irradiating the specimen to obtain the desired curvature in the perpendicular plane-is missed. It seems that independent control of curvature in multi-step bending can produce more complicated shapes and can be an exciting topic for researchers.

Table 2. Comparison of the irradiation scheme for laser forming of curved sheets [76].

\begin{tabular}{|c|c|c|c|c|c|}
\hline Reference & $\begin{array}{l}\text { Fabricated } \\
\text { Shape }\end{array}$ & $\begin{array}{l}\text { Irradiation } \\
\text { Scheme }\end{array}$ & Material & Laser Specification & Blank Dimensions \\
\hline $\begin{array}{c}\text { Chakraborty et al. } \\
\text { [92] }\end{array}$ & $\begin{array}{l}\text { bowl-shaped } \\
\text { surface }\end{array}$ & Radial scan & $\begin{array}{c}\text { AISI } 304 \\
\text { stainless steel }\end{array}$ & $\begin{array}{c}350 \mathrm{~W} \text { laser; } 2.8 \mathrm{~mm} \text { spot } \\
\text { diameter; } 0.45 \mathrm{~mm} / \mathrm{min} \text { scan } \\
\text { speed }\end{array}$ & $\varphi 100 \mathrm{~mm}, 1 \mathrm{~mm}$ thickness \\
\hline Liu and Yao [93] & $\begin{array}{c}\text { pillow and } \\
\text { saddle-shaped } \\
\text { surfaces }\end{array}$ & $\begin{array}{l}\text { Calculated } \\
\text { paths }\end{array}$ & 1010 mild steel & $\begin{array}{l}\text { 1000-1500 W laser; } 6 \mathrm{~mm} \\
\text { spot diameter; } 20-60 \mathrm{~mm} / \mathrm{s} \\
\text { scan speed }\end{array}$ & $140 \mathrm{~mm} \times 80 \mathrm{~mm} \times 0.89 \mathrm{~mm}$ \\
\hline $\begin{array}{l}\mathrm{Na} \text { and Kim [94] and } \\
\text { Kim and } \mathrm{Na} \text { [95] }\end{array}$ & $\begin{array}{l}\text { saddle-shaped } \\
\text { surface }\end{array}$ & $\begin{array}{l}\text { Calculated } \\
\text { paths }\end{array}$ & mild steel & $\begin{array}{c}100 \mathrm{~W} \text { laser; } 2 \mathrm{~mm} \text { spot } \\
\text { diameter; } 4-10 \mathrm{~mm} / \mathrm{s} \text { scan } \\
\text { speed }\end{array}$ & $30 \mathrm{~mm} \times 30 \mathrm{~mm} \times 0.8 \mathrm{~mm}$ \\
\hline Gao et al. [96] & ship hull shape & $\begin{array}{l}\text { Calculated } \\
\text { paths }\end{array}$ & S275 steel & $\begin{array}{l}\text { 400-500 W laser; } 3-5 \mathrm{~mm} \\
\text { spot diameter; } 20-40 \mathrm{~mm} / \mathrm{s} \\
\text { scan speed }\end{array}$ & $100 \mathrm{~mm} \times 100 \mathrm{~mm} \times 1.5 \mathrm{~mm}$ \\
\hline $\begin{array}{c}\text { Imani Shahabad et al. } \\
{[97,98]}\end{array}$ & $\begin{array}{l}\text { Dome-shaped } \\
\text { surface }\end{array}$ & $\begin{array}{c}\text { Spider } \\
\text { scanning paths }\end{array}$ & $\begin{array}{l}\text { AA } 6061-\mathrm{T} 6 \\
\text { aluminum } \\
\text { alloy }\end{array}$ & $\begin{array}{l}2500-3000 \mathrm{~W} \text { laser; } 5-7 \mathrm{~mm} \\
\text { spot diameter; } 60-100 \mathrm{~mm} / \mathrm{s} \\
\text { scan speed }\end{array}$ & $\varphi 150 \mathrm{~mm}, 2 \mathrm{~mm}$ thickness \\
\hline Shen et al. $[99,100]$ & $\begin{array}{l}\text { Pillow, warped } \\
\text { and saddle } \\
\text { shape }\end{array}$ & $\begin{array}{l}\text { Computational } \\
\text { scanning path }\end{array}$ & $\begin{array}{l}304 \text { stainless } \\
\text { steel }\end{array}$ & $\begin{array}{c}200 \mathrm{~W} \text { laser; } 1.7 \mathrm{~mm} \text { spot } \\
\text { diameter }\end{array}$ & $\begin{array}{l}100 \mathrm{~mm} \times 100 \mathrm{~mm} \times 2 \mathrm{~mm} ; \\
100 \mathrm{~mm} \times 100 \mathrm{~mm} \times 1 \mathrm{~mm}\end{array}$ \\
\hline Maji et al. [101] & $\begin{array}{l}\text { Dome-shaped } \\
\text { surface }\end{array}$ & $\begin{array}{l}\text { Cross (axial } \\
\text { and diagonal) } \\
\text { scanning paths }\end{array}$ & $\begin{array}{c}\text { AISI } 304 \\
\text { stainless steel }\end{array}$ & $\begin{array}{l}400-500 \mathrm{~W} \text { laser; } 2-3 \mathrm{~mm} \\
\text { spot diameter; } 30-40 \mathrm{~mm} / \mathrm{s} \\
\text { scan speed }\end{array}$ & $\begin{array}{r}60 \mathrm{~mm} \times 60 \mathrm{~mm} \times 1 \mathrm{~mm} \\
90 \mathrm{~mm} \times 90 \mathrm{~mm} \times 1 \mathrm{~mm} \\
120 \mathrm{~mm} \times 120 \mathrm{~mm} \times 1 \mathrm{~mm}\end{array}$ \\
\hline
\end{tabular}




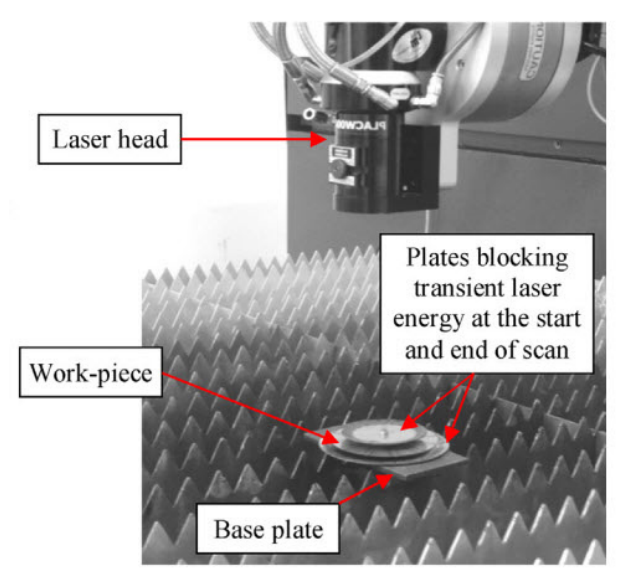

(a)
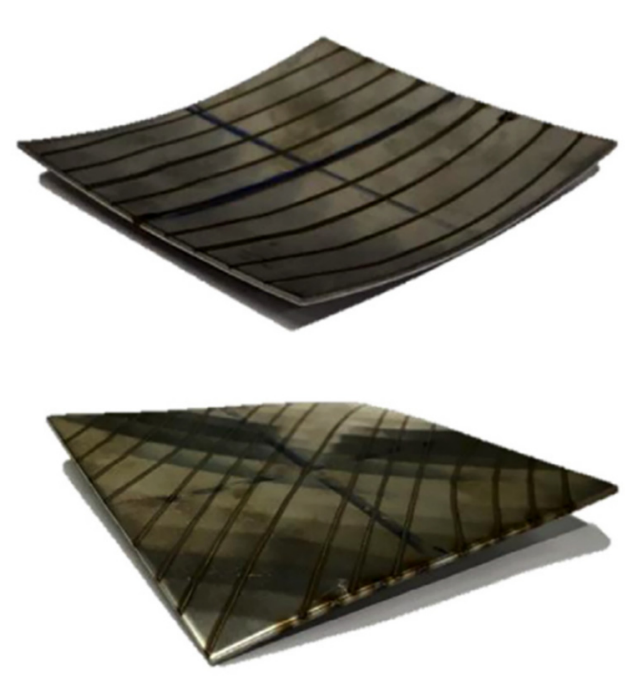

(c)

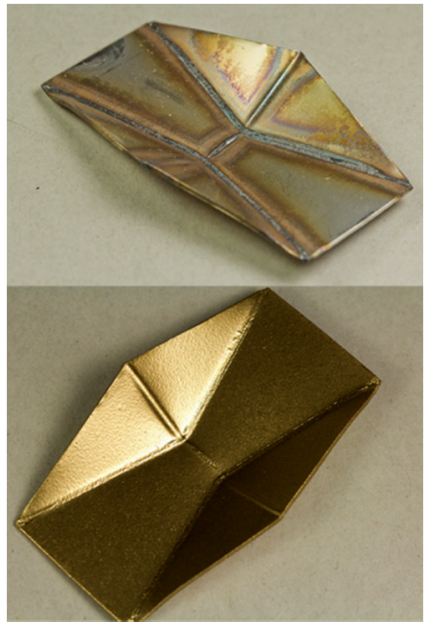

(b)

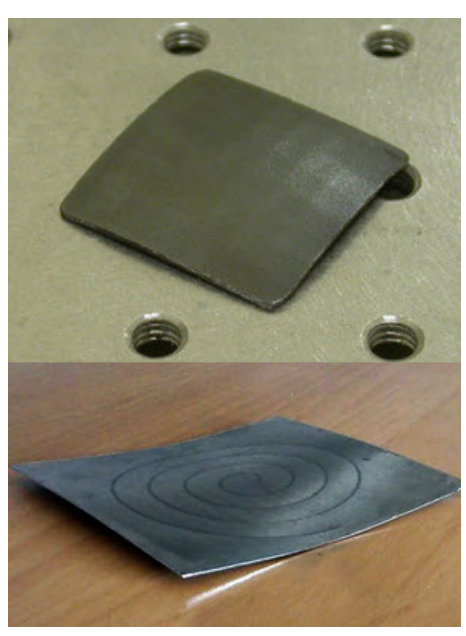

(d)

Figure 4. (a) Fabrication of a bowl shaped surface by laser forming [92], (Adapted from [92], with permission from Elsevier, 2020). (b) Origami Spoon [73], (Adapted from [73], with permission from Elsevier, 2020) (c) Pillow, and warped shape [99], (Adapted from [99], with permission from Elsevier, 2020). (d) Dome and saddle shaped surfaces [76,95]. (Adapted from [95], with permission from Elsevier, 2020).

\section{Analytical Approaches}

Several pieces of research have been implemented to determine the bending angle analytically. One of the oldest articles in this field is Liu et al. [102]. Some of the research focuses on combined analytical and numerical methods for estimation of bending angle. Analytical models use equations of the elastic-plastic bending moment and equilibrium of force and moment [103]. Li and Wang [35] developed an analytical model to predict the bending angle of laminated plates accurately (stainless steel-carbon steel laminated plate). The piecewise function predicts the temperature distribution along with the thickness of the sheet. The zones in which the temperature is above the recrystallization temperature will experience a plastic deformation during cooling. The bending angle will be calculated analytically by determining the depth of the plastic zone, yield strength function, and the equilibrium equations. In a recent study, an analytical approach for predicting the bending angle of a laser-formed sheet with a single laser scan has been developed. The temperature field has been determined by 
solving the 1-D transient heat conduction equation. The thermal strain and the induced thermal stress are obtained, and finally, the bending moment is assessed. The angle of sheet bending is determined according to the strain energy created due to the bending moment during the laser heating [104]. Recently, Kumar and Dixit [105] proposed an approach for the estimation of the temperature-dependent yield strength and modulus of elasticity. The approach consists of a straightforward solution and an inverse solution that relates the experimental data and finite element method to each other. Moreover, in another study, they developed a model to estimate the hardness of the laser bent parts. The kinetics of diffusional and non-diffusional phase transformation, latent heat generation during phase transformations, and the interaction of temperature and phase fraction on the variation of thermomechanical properties are three metallurgical phenomena should be considered in the analytical analysis [106]. The effect of preload during laser forming is essential. As discussed, force-assisted laser forming can bend sheets more effectively. An analytical model proposed by Guo et al. [107] for prediction of the bending angle in the presence of preload. The model is developed according to the buckling mechanism (BM) using thermal and preload stress and strain relationship in the heating zone and the buckling mechanism [107]. The edge effect is undesirable in laser forming, and the bending angle is not constant along the scanning line. An analytical solution to consider the edge effects in laser bending is suggested by Fauzi et al. [108].

The main challenges in the analytical model are the determination of the laser forming mechanism (thermal gradient mechanism (TGM), buckling mechanism (BM), the upsetting mechanism (UM), among others), analytical definition of mechanical properties (the definition of stress function according to strain, strain rate, temperature), non-linearity in geometry and properties, coupled thermal-structural analysis of bending, the effect of phase transformation, the residual stress remained in the workpiece, and stress relief during heating. Several developments can be attained in the field of the analytical model for the prediction of bending angle, strain field, residual stress distribution, and curvature radius. Joudaki and sedighi [109] proposed an analytical approach to predict residual stress during the bending of sheets. The model is developed to determine the effect of different material behavior on residual stress distribution. New analytical models can be derived by considering the stress as a function of temperature, strain, and coupled solving the structural and heat transfer equations.

\section{Other Applications of Laser Beam Technology}

A short pulse laser beam can be employed to fabricate micro-sized parts like MEMS parts [110]. Metal foams can be formed by laser forming [111-119]. Metal foams are a new category of materials which has a low density and good geometrical flexibility. Instead of applying a mechanical load, the laser irradiation heat produces a temperature gradient along with the thickness. The results show that the temperature gradient mechanism (TGM) is the primary mechanism of the closed-cell metal foams [113]. Stiffened parts and reinforced panels can be formed by laser beam irradiation [120-122]. The laser beam can be used in various processes like laser peen forming (LPF) [123-127], laser shock peening (LSP) [128,129], Laser solid forming (LSF) [130,131], laser folding [132], modification of mechanically bent parts (correction of spring back, over-bending or distortion of sheet [133]) and measuring the bending angle [134].

\section{Conclusions}

This review has briefly described the most remarkable and recent developments in laser-forming technology and applications involving single-layer, multilayer, and composite sheets. Topics covered include sheet bending by laser beam irradiation, tube bending, force assisted laser bending, optimization of process parameters, and analytical models in modeling. Doubly-curved parts have an essential role in the shipbuilding and aerospace industries and were discussed in a separate section. The laser beam technology can be used more creatively to fabricate special parts, such as saddle-shaped surfaces or the bending of micro-tubes. The experiences of the authors show that developing analytical solutions can help researchers to fabricate simple bending, but analytical solutions are not effective enough to 
manufacture accurate and complicated shapes. Combining numerical methods, statistical approaches, and experimental knowledge can be a proper solution for the manufacturing of intricate shapes.

Author Contributions: Conceptualization, Investigation and Methodology, M.S.; Formal Analysis and Funding acquisition, R.A.d.S; Validation and Writing-Original Draft Preparation, J.J.; Writing-Review and Editing, M.S., R.A.d.S., and J.J. All authors have read and agreed to the published version of the manuscript.

Funding: Ricardo J. Alves de Sousa acknowledges grants UID/EMS/0048 CENTRO-01-0145-FEDER-022083-Centro2020, European Regional Development Fund (ERDF).

Conflicts of Interest: The authors declare no conflict of interest.

\section{References}

1. Dixit, U.S.; Joshi, S.N.; Kant, R. Laser forming systems: A review. Int. J. Mechatr. Manuf. Sys. 2015, 8, 160-205. [CrossRef]

2. Das, B.; Biswas, P. A review of plate forming by line heating. J. Ship. Prod. Des. 2018, 34, 155-167. [CrossRef]

3. Kant, R.; Bhuyan, P.M.; Joshi, S.N. Experimental Studies on TGM and BM Dominated Curvilinear Laser Bending of Aluminum Alloy Sheets. In Lasers Based Manufacturing, Topics in Mining, Metallurgy and Materials Engineering. Proceedings of the 5th International and 26th All India Manufacturing Technology, Design and Research Conference (AIMTDR 2014), Guwahati, India, 12-14 December 2014; Joshi, S., Dixit, U., Eds.; Springer: New Delhi, India, 2015; pp. 69-91. [CrossRef]

4. Roohi, A.H.; Moslemi Naeini, H.; Hoseinpour Gollo, M.; Shahbazi Karami, J.; Imani Shahabad, S. Effects of temperature gradient magnitude on bending angle in laser forming process of aluminium alloy sheets. J. Comput. Appl. Res. Mech. Eng. 2016, 5, 97-109. [CrossRef]

5. Xu, L.; Li, W.; Wang, X.; Wan, M.; Jiang, M. Plastic deformation behavior in laser bending of elastic preloaded metal plate. Inte. J. Adv. Manuf. Tech. 2017, 90, 3397-3406. [CrossRef]

6. Rattan, A.; Jasra, Y.; Saxena, R.K. Prediction of bending behavior for laser forming of lime coated plain carbon steel using finite element method. Materials today: Proc. 2020, 28, 1943-1950. [CrossRef]

7. Abedi, H.R.; Hoseinpour Gollo, M. An experimental study of the effects of surface roughness and coating of $\mathrm{Cr}_{2} \mathrm{O}_{3}$ layer on the laser-forming process. Opt. Laser Technol. 2019, 109, 336-347. [CrossRef]

8. Fidder, H.; Admiraal, J.P.J.; Ocelík, V.; De Hosson, J.T.M. In situ digital image correlation observations of laser forming. Metals 2020, 10, 17. [CrossRef]

9. Gautam, S.S.; Singh, S.K.; Dixit, U.S. Laser Forming of Mild Steel Sheets Using Different Surface Coatings. In Lasers Based Manufacturing, Topics in Mining, Metallurgy and Materials Engineering. Proceedings of the 5th International and 26th All India Manufacturing Technology, Design and Research Conference (AIMTDR 2014), Guwahati, India, 12-14 December 2014; Joshi, S., Dixit, U., Eds.; Springer: New Delhi, India, 2015; pp. 17-39. [CrossRef]

10. Fetene, B.N.; Dixit, U.S.; Liao, H. Laser bending of friction stir processed and cement-coated sheets. Mater. Manuf. Process. 2017, 32, 1628-1634. [CrossRef]

11. Maji, K.; Pratihar, D.K.; Nath, A.K. Numerical and Experimental Studies on Pulsed Laser Forming of Sheet Metal. In Lasers Based Manufacturing, Topics in Mining, Metallurgy and Materials Engineering. Proceedings of the 5th International and 26th All India Manufacturing Technology, Design and Research Conference (AIMTDR 2014), Guwahati, India, 12-14 December 2014; Joshi, S., Dixit, U., Eds.; Springer: New Delhi, India, 2015; pp. 55-67. [CrossRef]

12. Kristiansen, E.; Kristiansen, M.; Endelt, B.; Thomsen, A.N. Investigation of the profile of laser bends with variable scan distance. Proc. Manuf. 2019, 36, 192-199. [CrossRef]

13. Zhang, Y.; Dong, W.; Qiao, Y.; Zhang, C. Edge effect investigation of DP980 steel sheet in multiple laser scanning process. Int. J. Precis. Eng. Manuf. 2019, 20, 319-326. [CrossRef]

14. Zhang, Y.J.; Kim, J.; Song, J.H.; Lee, G.A.; Lee, H.J.; Lee, N.K. FEM analysis for laser bending process of DP980 steel sheet. Int. J. Precis. Eng. Manuf. 2015, 16, 315-321. [CrossRef]

15. Maji, K.; Pratihar, D.K.; Nath, A.K. Experimental investigations, modeling, and optimization of multi-scan laser forming of AISI 304 stainless steel sheet. Int. J. Adv. Manuf. Technol. 2016, 83, 1441-1455. [CrossRef]

16. Song, J.H.; Lee, G.A.; Jung, K.H.; Park, S.J. Laser irradiated bending characteristics of the ultra-high strength steel sheets. Int. J. Automot. Techn. 2015, 16, 89-96. [CrossRef] 
17. Dixit, U.S.; Fetene, B.N. A finite element modelling of laser bending of friction stir welded aluminium 5052-H32 sheets. Int. J. Mechatr. Manuf. Sys. 2016, 9, 215-236. [CrossRef]

18. Fetene, B.N.; Kumar, V.; Dixit, U.S.; Echempati, R. Numerical and experimental study on multi-pass laser bending of AH36 steel strips. Opt. Laser Technol. 2018, 99, 291-300. [CrossRef]

19. Mjali, K.V.; Els-Botes, A.; Mashinini, P.M. The Effects of Laser and Mechanical Forming on the Hardness and Microstructural Layout of Commercially Pure Grade 2 Titanium Alloy Plates. In Volume 2: Additive Manufacturing; Materials, Proceedings of the ASME 2017 12th International Manufacturing Science and Engineering Conference, Los Angeles, CA, USA, 4-8 June 2017; Paper No: MSEC2017-2603; p. V002T03A009. Available online: https://asmedigitalcollection.asme.org/MSEC/proceedings-bstract/ MSEC2017/50732/V002T03A009/269465 (accessed on 3 November 2020). [CrossRef]

20. Akinlabi, S.; Mashinini, M.; Akinlabi, E. Effect of Temperature on the Evolved Microstructure During Laser Beam Forming of Sheet Steels. In Volume 2: Advanced Manufacturing; Proceedings of the ASME 2017 International Mechanical Engineering Congress and Exposition, Tampa, FL, USA, 3-9 November 2017; Paper No: IMECE2017-72044; p. V002T02A069. Available online: https://asmedigitalcollection.asme.org/IMECE/ proceedings-abstract/IMECE2017/58356/V002T02A069/265599 (accessed on 3 November 2020). [CrossRef]

21. Mjali, K.V.; Els-Botes, A.; Mashinini, P.M. Residual stress distribution and the concept of total fatigue stress in laser and mechanically formed commercially pure grade 2 titanium alloy plates. ASME. J. Manuf. Sci. Eng. 2018, 140, 061005-061014. [CrossRef]

22. Kant, R.; Joshi, S.N. Thermo-mechanical studies on bending mechanism, bend angle and edge effect during multi-scan laser bending of magnesium M1A alloy sheets. J. Manuf. Process. 2016, 23, 135-148. [CrossRef]

23. Kotobi, M.; Honarpisheh, M. Experimental and numerical investigation of through-thickness residual stress of laser-bent Ti samples. J. Strain Anal. Eng. 2017, 52, 347-355. [CrossRef]

24. Paramasivan, K.; Das, S.; Marimuthu, S.; Misra, D. Increment in laser bending angle by forced bottom cooling. Int. J. Adv. Manuf. Technol. 2018, 94, 2137-2147. [CrossRef]

25. Kant, R.; Joshi, S.N. A Numerical Investigation into the Effect of Forced Convection Cooling on the Performance of Multi-scan Laser Bending Process. In Application of Lasers in Manufacturing, Proceeding of the 6th International and the 27th All India Manufacturing Technology, Design and Research (AIMTDR 2016) conference, Pune, India, 16-18 December 2016; Dixit, U., Joshi, S., Davim, J., Eds.; Springer: Singapore, 2019; pp. 21-43. [CrossRef]

26. Fetene, B.N.; Dixit, U.S. Finite Element Simulations of Laser Bending of Small Sized Sheets. In Lasers Based Manufacturing, Topics in Mining, Metallurgy and Materials Engineering. Proceedings of the 5th International and 26th All India Manufacturing Technology, Design and Research Conference (AIMTDR 2014), Guwahati, India, 12-14 December 2014; Joshi, S., Dixit, U., Eds.; Springer: New Delhi, India, 2015; pp. 41-53. [CrossRef]

27. Safari, M.; Ebrahimi, M. Numerical investigation of laser bending of perforated sheets. J. Adv. Des. Manuf. Technol. 2016, 9, 53-60.

28. Lambiase, F.; Di Ilio, A.; Paoletti, A. Productivity in multi-pass laser forming of thin AISI 304 stainless steel sheets. Int. J. Adv. Manuf. Technol. 2016, 86, 259-268. [CrossRef]

29. Safari, M.; Mostaan, H.; Farzin, M. Laser bending of tailor machined blanks: Effect of start point of scan path and irradiation direction relation to step of the blank. Alex. Eng. J. 2016, 55, 1587-1594. [CrossRef]

30. Safari, M.; Joudaki, J. Prediction of bending angle for laser forming of tailor machined blanks by neural network. Iranian J. Mater. Form. 2018, 5, 47-57. [CrossRef]

31. Seyedkashi, S.M.H.; Abazari, H.D.; Gollo, M.H.; Woo, Y.Y.; Moon, Y.H. Characterization of laser bending of SUS304L/C11000 clad sheets. J. Mech. Sci. Technol. 2019, 33, 3223-3230. [CrossRef]

32. Kotobi, M.; Honarpisheh, M. Through-depth residual stress measurement of laser bent steel-titanium bimetal sheets. J. Strain Anal. Eng. 2018, 53, 130-140. [CrossRef]

33. Kotobi, M.; Mansouri, H.; Honarpisheh, M. Investigation of laser bending parameters on the residual stress and bending angle of St-Ti bimetal using FEM and neural network. Opt. Laser Technol. 2019, 116, 265-275. [CrossRef]

34. Li, Z.; Wang, X.; Luo, Y. Numerical simulation of stainless steel-carbon steel laminated plate considering interface in pulsed laser bending. Materials 2019, 12, 1410. [CrossRef] [PubMed]

35. Li, Z.; Wang, X. Analytical model for estimating bending angle in laser bending of 304 stainless steel/Q235 carbon steel laminated plate. J. Laser Appl. 2019, 31, 042012-1-042012-12. [CrossRef] 
36. Wang, X.; Ma, X.; Li, Z.; Wang, R. A study of thickening phenomenon in laser bending zone of a metal laminated plate. Proc. CIRP. 2016, 42, 454-459. [CrossRef]

37. D' Souza, A.; Palani, I.A.; Naikwad, S.; Padmanabhan, R.; Shanmugam, S.; Natu, H. Parametric Investigation in Laser Forming of $8 \mathrm{~mm}$ FE-410 Plate Using High Power $\mathrm{CO}_{2}$ Laser and Its Bend Angle Prediction. Mater. Today Proc. 2015, 2, 2013-2021. [CrossRef]

38. Seyedkashi, S.M.H.; Hoseinpour Gollo, M.; Biao, J.; Moon, Y.H. Laser bendability of SUS430/C11000/SUS430 laminated composite and its constituent layers. Met. Mater. Int. 2016, 22, 527-534. [CrossRef]

39. Li, Z.; Wang, X. Numerical simulation of warping deformation on metal composite plate during laser bending. J. Inf. Laser Eng. 2018, 47, 506004-0506010. [CrossRef]

40. Liu, H.; Zhang, W.; Gau, J.T.; Shen, Z.; Ma, Y.; Zhang, G.; Wang, X. Feature size effect on formability of multilayer metal composite sheets under microscale laser flexible forming. Metals 2017, 7, 275. [CrossRef]

41. Gisario, A.; Mehrpouya, M.; Rahimzadeh, A.; De Bartolomeis, A.; Barletta, M. Prediction model for determining the optimum operational parameters in laser forming of fiber-reinforced composites. Adv. Manuf. 2020, 8, 242-251. [CrossRef]

42. Gisario, A.; Barletta, M. Laser forming of glass laminate aluminium reinforced epoxy (GLARE): On the role of mechanical, physical and chemical interactions in the multi-layers material. Opt. Laser. Eng. 2018, 110, 364-376. [CrossRef]

43. Zhang, Z.; Hu, Y.; Yao, Z. Shape prediction for laser peen forming of fiber metal laminates by experimentally determined eigenstrain. J. Manuf. Sci. Eng. 2017, 139, 041004-041013. [CrossRef]

44. Zhang, Z.; Hu, Y.; Yao, Z. An Experiment-Based Model to Determine Eigenstrain in Fibre Metal Laminates Induced by Laser Peen Forming. In Volume 1: Processing, Proceedings of the ASME 2016 11th International Manufacturing Science and Engineering Conference, Blacksburg, USA, June 27-July 1 2016; Paper No: MSEC2016-8544; p. V001T02A027. Available online: https://asmedigitalcollection.asme.org/MSEC/ proceedings-abstract/MSEC2016/49897/V001T02A027/268523 (accessed on 3 November 2020). [CrossRef]

45. Gisario, A.; Mehrpouya, M.; Venettacci, S.; Barletta, M. Laser-assisted bending of titanium grade-2 sheets: Experimental analysis and numerical simulation. Opt. Laser. Eng. 2017, 92, 110-119. [CrossRef]

46. Gisario, A.; Barletta, M.; Venettacci, S. Improvements in springback control by external force laser-assisted sheet bending of titanium and aluminum alloys. Opt. Laser Technol. 2016, 86, 46-53. [CrossRef]

47. Gisario, A.; Barletta, M.; Venettacci, S.; Veniali, F. Laser-assisted bending of sharp angles with small fillet radius on stainless steel sheets: Analysis of experimental set-up and processing parameters. Laser. Manuf. Mater. Process. 2015, 2, 57-73. [CrossRef]

48. Nowak, Z.; Nowak, M.; Widłaszewski, J.; Kurp, P. Experimental and Numerical Investigation on Laser-Assisted Bending of Pre-Loaded Metal Plate. In AIP Conference Proceedings Vol. 1922, Proceedings of the 22nd International Conference on Computer Methods in Mechanics, Lublin, Poland, 13-16 September 2017; AIP Publishing: New York, NY, USA; p. 140006. [CrossRef]

49. Ponticelli, G.S.; Guarino, S.; Giannini, O. A fuzzy logic-based model in laser-assisted bending springback control. Int. J. Adv. Manuf. Technol. 2018, 95, 3887-3898. [CrossRef]

50. Fetene, B.N.; Shufen, R.; Dixit, U.S. FEM-based neural network modeling of laser-assisted bending. Neural. Comput. Appl. 2018, 29, 69-82. [CrossRef]

51. Shi, Y.; Zhang, C.; Sun, G.; Li, C. Study on reducing edge effects by using assistant force in laser forming. J. Mater. Process. Tech. 2016, 227, 169-177. [CrossRef]

52. Dutta, P.P.; Kalita, K.; Dixit, U.S.; Liao, H. Magnetic-force-assisted straightening of bent mild steel strip by laser irradiation. Laser Manuf. Mater. Process. 2017, 4, 206-226. [CrossRef]

53. Dutta, P.P.; Kalita, K.; Dixit, U.S. Electromagnetic-force-assisted bending and straightening of ah36 steel strip by laser irradiation. Laser Manuf. Mater. Process. 2018, 5, 201-221. [CrossRef]

54. Safari, M. A study on the laser tube bending process: Effects of the irradiating length and the number of irradiating passes. Iranian J. Mater. Form. 2020, 7, 46-53. [CrossRef]

55. Khandandel, S.E.; Seyedkashi, S.M.H.; Moradi, M. A novel path strategy design for precise 2D and 3D laser tube forming process; experimental and numerical investigation. Optik 2020, 206, 164302. [CrossRef]

56. Li, F.; Liu, S.; Shi, A.; Shi, Q.; Li, Y. Research on laser thread form bending of stainless steel tube. Int. J. Precis. Eng. Manuf. 2019, 20, 893-903. [CrossRef] 
57. Imhan, K.I.; Baharudin, B.T.H.T.; Zakaria, A.; Ismail, M.I.S.B.; Alsabti, N.M.H.; Ahmad, A.K. Improve the material absorption of light and enhance the laser tube bending process utilizing laser softening heat treatment. Opt. Laser Technol. 2018, 99, 15-18. [CrossRef]

58. Imhan, K.I.; Baharudin, B.T.H.T.; Zakaria, A.; Ismail, M.I.S.B.; Alsabti, N.M.H.; Ahmad, A.K. Investigation of material specifications changes during laser tube bending and its influence on the modification and optimization of analytical modeling. Opt. Laser Technol. 2017, 95, 151-156. [CrossRef]

59. Che Jamil, M.S.; Imam Fauzi, E.R.; Juinn, C.S.; Sheikh, M.A. Laser bending of pre-stressed thin-walled nickel micro-tubes. Opt. Laser Technol. 2015, 73, 105-117. [CrossRef]

60. Keshtiara, M.; Golabi, S.; Tarkesh Esfahani, R. Multi-objective optimization of stainless steel 304 tube laser forming process using GA. Eng. Comput. 2019, 1-17. [CrossRef]

61. Folkersma, G.; Brouwer, D.; Römer, G. Microtube laser forming for precision component alignment. ASME. J. Manuf. Sci. Eng. 2016, 138, 081012-1-081012-6. [CrossRef]

62. Kumar, V.; Dixit, U.S. Selection of process parameters in a single-pass laser bending process. Eng. Optimiz. 2018, 50, 1609-1624. [CrossRef]

63. Lambiase, F.; Di Ilio, A.; Paoletti, A. Optimization of multi-pass laser bending by means of soft computing techniques. Proc. CIRP 2015, 33, 502-507. [CrossRef]

64. Omidvar, M.; Kashiry Fard, R.; Sohrabpoor, H.; Teimouri, R. Selection of laser bending process parameters for maximal deformation angle through neural network and teaching-learning-based optimization algorithm. Soft. Comput. 2015, 19, 609-620. [CrossRef]

65. Kant, R.; Joshi, S.N.; Dixit, U.S. An integrated FEM-ANN model for laser bending process with inverse estimation of absorptivity. Mech. Adv. Mater. Mod. Process. 2015, 1, 1-12. [CrossRef]

66. Shen, H.; Zheng, Y.; Wang, H.; Yao, Z. Heating position planning in laser forming of single curved shapes based on probability convergence. ASME. J. Manuf. Sci. Eng. 2016, 138, 091003-1-091003-7. [CrossRef]

67. Nejati, M.R.; Gollo, M.H.; Tajdari, M.; Ghaffarian, H. Input value prediction of parameters in laser bending using fuzzy and PSO. Soft. Comput. 2018, 22, 2189-2203. [CrossRef]

68. Maji, K.; Chakraborty, S.S.; Pratihar, D.K.; Nath, A.K. Inverse analysis and multi-objective optimization of coupling mechanism based laser forming process. Sadhana Acad. P. Eng. S. 2020, 45, 8. [CrossRef]

69. Boonpuang, R.; Mongkolwongroj, M.; Sakulkalavek, A.; Sakdanuphab, R. Empirical modeling and optimization of laser bending process parameters using the central composite design method for HDD slider PSA/RSA adjustment. Laser Manuf. Mater. Process. 2020, 7, 290-304. [CrossRef]

70. Ponticelli, G.S.; Guarino, S.; Giannini, O.; Tagliaferri, F.; Venettacci, S.; Ucciardello, N.; Baiocco, G. Springback control in laser-assisted bending manufacturing process by using a fuzzy uncertain model. Proc. CIRP 2020, 88, 491-496. [CrossRef]

71. Behera, A.; Sahu, P.S.; Patel, S.K. Application of Taguchi methodology for optimization of process parameters in laser bending of Al sheet. Mater. Today Proc. 2020, 26, 2323-2327. [CrossRef]

72. Cook, F.; Celentano, D.; Ramos-Grez, J. Experimental-numerical methodology for the manufacturing of cranial prosthesis via laser forming. Int. J. Adv. Manuf. Technol. 2016, 86, 2187-2196. [CrossRef]

73. Gisario, A.; Mehrpouya, M.; Venettacci, S.; Mohammadzadeh, A.; Barletta, M. Laser Origami (LO) of three-dimensional (3D) components: Experimental analysis and numerical modelling. J. Manuf. Process. 2016, 23, 242-248. [CrossRef]

74. Mehrpouya, M.; Huang, H.; Venettacci, S.; Gisario, A. Laser Origami (LO) of three-dimensional (3D) components: Experimental analysis and numerical modeling-part II. J. Manuf. Process. 2019, 39, 192-199. [CrossRef]

75. Gisario, A.; Barletta, M.; Venettacci, S.; Veniali, F. Progress in tridimensional (3d) laser forming of stainless steel sheets. Laser Manuf. Mater. Process. 2015, 2, 148-163. [CrossRef]

76. Safari, M.; Alves de Sousa, R.; Joudaki, J. Fabrication of saddle-shaped surfaces by a laser forming process: An experimental and statistical investigation. Metals 2020, 10, 883. [CrossRef]

77. Safari, M.; Farzin, M. A new method for production of double-curvature dome-shaped part: Statistical analysis of the effects of process parameters on the radius of curvature of obtained dome shape. J. Ship. Prod. Des. 2018, 34, 85-93. [CrossRef]

78. Safari, M.; Farzin, M.; Mostaan, H. A novel method for laser forming of two-step bending of a dome shaped part. Iranian J. Mater. Form. 2017, 4, 1-14. [CrossRef] 
79. Safari, M. A novel and comprehensive method for laser forming of cylindrical surfaces with arbitrary radius of curvature. Modares Mech. Eng. 2016, 15, 9-16.

80. Safari, M.; Farzin, M. Experimental investigation of laser forming of a saddle shape with spiral irradiating scheme. Opt. Laser Technol. 2015, 66, 146-150. [CrossRef]

81. Safari, M. Experimental and numerical investigation of laser forming of a doubly curved saddle shape with spiral irradiating scheme. J. Adv. Manuf. Technol. 2015, 9, 51-60.

82. Safari, M.; Farzin, M. A study on laser bending of tailor machined blanks with various irradiating schemes. J. Mater. Process. Technol. 2014, 214, 112-122. [CrossRef]

83. Safari, M.; Farzin, M.; Ghaei, A. Investigation into the effects of process parameters on bending angle in the laser bending of tailor machined blanks based on a statistical analysis. J. Laser Appl. 2013, 25, 052001-1-052001-10. [CrossRef]

84. Safari, M.; Mostaan, H. Experimental and numerical investigation of laser forming of cylindrical surfaces with arbitrary radius of curvature. Alex. Eng. J. 2016, 55, 1941-1949. [CrossRef]

85. Dehghan, S.H.; Loh-Mousavi, M.; Farzin, M.; Safari, M. Laser forming of metallic dome-shaped parts using spiral and radial-circular scan paths. J. Adv. Manuf. Technol. 2016, 10, 29-44.

86. Hoseinpour Gollo, M.; Nadi, G.; Mehdi, M.; Abbaszadeh, M. Experimental and numerical study of spiral scan paths on cap laser forming. J. Laser Appl. 2015, 27, 012002-1-012002-9. [CrossRef]

87. Abolhasani, D.; Seyedkashi, S.M.H.; Hoseinpour Gollo, M.; Moon, Y.H. Effects of laser beam parameters on bendability and microstructure of stainless steel in three-dimensional laser forming. Appl. Sci. 2019, 9, 4463. [CrossRef]

88. Kant, R.; Bhuyan, P.M.; Joshi, S.N. Experimental Studies on Curvilinear Laser Bending of Thin Sheets. Proceedings of the International Conference on Advanced Technologies for Societal Applications (Techno-Societal 2016), Pandharpur, India, 20-21 December 2016; Pawar, P., Ronge, B., Balasubramaniam, R., Seshabhattar, S., Eds.; Springer: Cham, Switzerland, 2018. [CrossRef]

89. Navarrete, Á.; Celentano, D. Effect of workpiece geometry using circular scan patterns in sheet laser forming processes. Int. J. Adv. Manuf. Technol. 2018, 96, 1835-1846. [CrossRef]

90. Navarrete, Á.; Cook, F.; Celentano, D.; Cruchaga, M.; García-Herrera, C. Numerical simulation and experimental validation of sheet laser forming processes using general scanning paths. Materials 2018, 11, 1262. [CrossRef]

91. Abolhasani, D.; Seyedkashi, S.M.H.; Kim, Y.T.; Hoseinpour Gollo, M.; Moon, Y.H. A double raster laser scanning strategy for rapid die-less bending of 3D shape. J. Mater. Res. Technol. 2019, 8, 4741-4756. [CrossRef]

92. Chakraborty, S.S.; Racherla, V.; Nath, A.K. Thermo-mechanical finite element study on deformation mechanics during radial scan line laser forming of a bowl shaped surface out of a thin sheet. J. Manuf. Process. 2018, 31, 593-604. [CrossRef]

93. Liu, C.; Yao, Y.L. FEM-based process design for laser forming of doubly curved shapes. J. Manuf. Process. 2005, 7, 109-121. [CrossRef]

94. Na, S.J.; Kim, J.T. 3D laser forming strategies for sheet metal by geometrical information. Int. J. Mater. Form. 2008, 1, 1367-1370. [CrossRef]

95. Kim, J.; Na, S.J. 3D laser-forming strategies for sheet metal by geometrical information. Opt. Laser Technol. 2009, 41, 843-852. [CrossRef]

96. Gao, H.; Sheikholeslami, G.; Dearden, G.; Edwardson, S.P. Reverse analysis of scan strategies for controlled 3D laser forming of sheet metal. Proc. Eng. 2017, 183, 369-374. [CrossRef]

97. Shahabad, S.I.; Naeini, H.M.; Roohi, A.H.; Soltanpour, M.; Tavakoli, A. Height prediction of dome-shaped products in laser forming process. Int. J. Adv. Manuf. Technol. 2017, 88, 2227-2236. [CrossRef]

98. Shahabad, S.I.; Naeini, H.M.; Roohi, A.H.; Tavakoli, A.; Nasrollahzade, M. Experimental investigation of laser forming process to produce dome-shaped products. Int. J. Adv. Manuf. Technol. 2017, 90, 1051-1057. [CrossRef]

99. Shen, H.; Zhou, W.; Wang, H. Laser forming of doubly curved plates using minimum energy principle and comprehensive strain control. Int. J. Mech. Sci. 2018, 145, 42-52. [CrossRef]

100. Shen, H.; Wang, H.; Zhou, W. Process modelling in laser forming of doubly-curved sheets from cylinder shapes. J. Manuf. Process. 2018, 35, 373-381. [CrossRef]

101. Maji, K.; Pratihar, D.K.; Nath, A.K. Laser forming of a dome shaped surface: Experimental investigations, statistical analysis and neural network modeling. Opt. Laser Eng. 2014, 53, 31-42. [CrossRef] 
102. Liu, F.R.; Chan, K.C.; Tang, C.Y. Theoretical analysis of deformation behavior of aluminum matrix composites in laser forming. Mater. Sci. Eng. A 2005, 396, 172-180. [CrossRef]

103. Eideh, A.; Dixit, U.S.; Echempati, R. A Simple Analytical Model of Laser Bending Process. In Lasers Based Manufacturing, Topics in Mining, Metallurgy and Materials Engineering. Proceedings of the 5th International and 26th All India Manufacturing Technology, Design and Research Conference (AIMTDR 2014), Guwahati, India, 1-15 December 2014; Joshi, S., Dixit, U., Eds.; Springer: New Delhi, India, 2015. [CrossRef]

104. Mulay, S.; Paliwal, V.; Babu, N.R. Analytical model for prediction of bend angle in laser forming of sheets. Int. J. Adv. Manuf. Technol. 2020, 109, 699-715. [CrossRef]

105. Kumar, V.; Dixit, U.S. Estimation of temperature-dependent yield strength and modulus of elasticity during laser bending. Measurement 2020, 154, 107515. [CrossRef]

106. Kumar, V.; Dixit, U.S. A model for the estimation of hardness of laser bent strips. Opt. Laser Technol. 2018, 107, 491-499. [CrossRef]

107. Guo, Y.; Shi, Y.; Wang, X.; Sun, R.; Bing, Z. An analytical model of laser bending angle under preload. Int. J. Adv. Manuf. Technol. 2020, 108, 2569-2577. [CrossRef]

108. Imam Fauzi, E.R.; Jamil, M.S.C.; Samad, Z.; Sheikh, M.A.; Najib, A.M. Influence of non-conventional beam profile on edge effects in laser forming of AISI 304 stainless steel plate. Int. J. Adv. Manuf. Technol. 2019, 104, 1593-1601. [CrossRef]

109. Joudaki, J.; Sedighi, M. Effect of material's behavior on residual stress distribution in elastic-plastic beam bending: An analytical solution. P. I. Mech. Eng. L-J. Mat. 2017, 231, 361-372. [CrossRef]

110. Manouchehry nya, R.; Peirovi, S.; Alipour, R.; Farokhi Nejad, A. Finite element analysis of micro scale laser bending of a steel sheet metal subjected to short pulse shock wave. Proc. Manuf. 2015, 2, 397-401. [CrossRef]

111. Bucher, T.; Cardenas, S.; Verma, R.; Li, W.; Lawrence Yao, Y. Laser forming of sandwich panels with metal foam cores. ASME. J. Manuf. Sci. Eng. 2018, 140, 111015-1-111015-12. [CrossRef]

112. Roohi, A.H.; Moslemi Naeini, H.; Hoseinpour Gollo, M.; Soltanpour, M.; Bruschi, S.; Ghiotti, A. Forming of closed-cell aluminum foams under thermal loadings: Experimental investigation. Int. J. Adv. Manuf. Technol. 2018, 95, 3919-3928. [CrossRef]

113. Zhang, M.; Chen, C.; Huang, Y.; Zou, T. Bending processing and mechanism of laser forming pure aluminum metal foam. Int. J. Adv. Manuf. Technol. 2018, 94, 1849-1856. [CrossRef]

114. Zhang, M.; Jun Chen, C.; Brandal, G.; Bian, D.; Lawrence Yao, Y. Experimental and numerical investigation of laser forming of closed-cell aluminum foam. ASME. J. Manuf. Sci. Eng. 2016, 138, 021006-1-021006-8. [CrossRef]

115. Bucher, T.; Young, A.; Zhang, M.; Chen, C.J.; Lawrence Yao, Y. Thermally induced mechanical response of metal foam during laser forming. ASME. J. Manuf. Sci. Eng. 2018, 140, 041004-1-041004-12. [CrossRef]

116. Bucher, T.; Young, A.; Zhang, M.; Chen, C.J.; Yao, L.Y. Bending Mechanism Analysis for Laser Forming of Metal Foam. In Volume 1: Processes. Proceedings of the ASME 2017 12th International Manufacturing Science and Engineering Conference, Los Angeles, CA, USA, 4-8 June 2017; Paper No: MSEC2017-3026; p. V001T02A060. Available online: https://asmedigitalcollection.asme.org/MSEC/proceedings-abstract/ MSEC2017/50725/V001T02A060/268607 (accessed on 3 November 2020). [CrossRef]

117. Mohammad Shahid, R.; Srinu, T.; Datta, S.; Saha, P. Investigating the Effect of Process Parameters and Scan Strategy During Laser Forming of Thin Open Celled Aluminium Foam. In Volume 4: Processes. Proceedings of the ASME 2018 13th International Manufacturing Science and Engineering Conference, TX, USA, 18-22 June 2018; Paper No: MSEC2018-6591; p. V004T03A059. Available online: https://asmedigitalcollection.asme.org/MSEC/ proceedings-abstract/MSEC2018/51388/V004T03A059/277111 (accessed on 3 November 2020). [CrossRef]

118. Bucher, T.; Zhang, M.; Chen, C.J.; Verma, R.; Li, W.; Lawrence Yao, Y. Laser forming of metal foam sandwich panels: Effect of panel manufacturing method. ASME. J. Manuf. Sci. Eng. 2019, 141, 051006-1-051006-11. [CrossRef]

119. Bucher, T.; Finn, C.; Verma, R.; Li, W.; Lawrence Yao, Y. 3D laser forming of metal foam sandwich panels. ASME. J. Manuf. Sci. Eng. 2020, 142, 081008-1-081008-11. [CrossRef]

120. Fu, S.; Yang, L.; Zhang, H.; Wang, Y.; Chi, G. Analyses of effects of process parameters on laser bending of stiffened panels. Int. J. Precis. Eng. Manuf. 2018, 19, 593-604. [CrossRef]

121. Fu, S.; Yang, L.; Zhang, H.; Wang, Y.; Chi, G. Laser forming of the panel with crossed reinforcing bars. Int. J. Precis. Eng. Manuf. 2017, 92, 3673-3692. [CrossRef] 
122. Fu, S.; Yang, L.; Zhang, H.; Wang, Y.; Chi, G.; Ding, Y. Numerical simulation of the twist deformation for the stiffened panel with laser forming. Int. J. Precis. Eng. Manuf. 2018, 19, 1569-1582. [CrossRef]

123. Hu, Y.; Xie, Y.; Wu, D.; Yao, Z. Quantitative evaluation of specimen geometry effect on bending deformation of laser peen forming. Int. J. Mech. Sci. 2019, 150, 404-410. [CrossRef]

124. Luo, M.; Hu, Y.; Qian, D.; Yao, Z. Numerical modeling and mechanism analysis of hybrid heating and shock process for laser-assisted laser peen forming. ASME. J. Manuf. Sci. Eng. 2018, 140, 111009-1-111009-10. [CrossRef]

125. Sagisaka, Y.; Yamashita, K.; Ueta, H. Efficiency improvement of thin-sheet-metal bending by femtosecond laser peen forming. Proc. Manuf. 2018, 15, 1314-1321. [CrossRef]

126. Hu, Y.; Luo, M.; Yao, Z. Increasing the capability of laser peen forming to bend titanium alloy sheets with laser-assisted local heating. Mater. Design. 2016, 90, 364-372. [CrossRef]

127. Hu, Y.; Zheng, X.; Wang, D.; Zhang, Z.; Xie, Y.; Yao, Z. Application of laser peen forming to bend fibre metal laminates by high dynamic loading. J. Mater. Process. Tech. 2015, 226, 32-39. [CrossRef]

128. Peng, C.; Xiao, Y.; Wang, Y.; Guo, W. Effect of laser shock peening on bending fatigue performance of AISI 9310 steel spur gear. Opt. Laser Technol. 2017, 94, 15-24. [CrossRef]

129. Shen, N.; Ding, H. Surface integrity analysis of laser peen micro-bending without protective coating. Proc. CIRP 2016, 45, 315-318. [CrossRef]

130. Tan, H.; Chen, Y.; Feng, Z.; Hou, W.; Fan, W.; Lin, X. A real-time method to detect the deformation behavior during laser solid forming of thin-wall structure. Metals 2020, 10, 508. [CrossRef]

131. Wang, X.; Li, C.; Ma, Y.; Shen, Z.; Sun, X.; Sha, C.; Gao, S.; Li, L.; Liu, H. An experimental study on micro clinching of metal foils with cutting by laser shock forming. Materials 2016, 9, 571. [CrossRef]

132. Lazarus, N.; Smith, G.L. Laser folding in a roll-to-roll manufacturing process. Lasers Manuf. Mater. Process. 2018, 5, 237-247. [CrossRef]

133. Chakraborty, S.S.; More, H.; Racherla, V.; Nath, A.K. Modification of bent angle of mechanically formed stainless steel sheets by laser forming. J. Mater. Process. Tech. 2015, 222, 128-141. [CrossRef]

134. Thomsen, A.N.; Kristiansen, M.; Kristiansen, E.; Endelt, B. Online measurement of the surface during laser forming. Int. J. Adv. Manuf. Technol. 2020, 107, 1569-1579. [CrossRef]

Publisher's Note: MDPI stays neutral with regard to jurisdictional claims in published maps and institutional affiliations.

(C) 2020 by the authors. Licensee MDPI, Basel, Switzerland. This article is an open access article distributed under the terms and conditions of the Creative Commons Attribution (CC BY) license (http://creativecommons.org/licenses/by/4.0/). 